\title{
電気めっき工場排水からの銅の電解回収 を目的とした銅沈殿の生成方法
}

\author{
縄舟 秀美* ・水本 省三* ・ 川崎 元雄* \\ Preparation of Copper Precipitate for Electrolytic Copper \\ Recovery from Electroplating Industry Wastewater
}

Hidemi NAWAFUNE*, Shozo MIZUMOTO*, Motoo KAWASAKI*

\begin{abstract}
Methods for precipitating copper ions in industrial waste water were investigated to obtain a precipitate of low water content with high filtration rate. Such a precipitate is favorable for electrolytical metal recovery in which the sludge is supplied to the anode compartment of a diaphragm cell. With addition of alkali carbonate or alkali hydrogen carbonate to a copper sulfate solution, a bluish white precipitate was formed initially. This precipitate changed gradually (but in a short time on warming) to green crystalline Malachite $\mathrm{Cu}(\mathrm{OH})\left(\mathrm{CO}_{3}\right)_{0.5}$, characterized by outstanding filtration rate and low water content ( $20 \%$ or less, as filtrated). The electrolytic recovery of copper from Malachite is then technically easy and economical.
\end{abstract}

\section{1. 緒言}

金属関連工場の排水等に含まれる重金属イオンを沈殿 分離して排水を無害化すると共に，得られたスラッジを 直接電解槽に供給して金属を電解回収するプロセス1)で は, 中和沈降処理後の処理液中の重金属分濃度が低いだ けでなく，凝集剤を用いなくても固液分離が容易で水分 およびその他の電解液中に蓄積する成分の少ない沈殿で あることが望ましい。このことはスラッジからの金属の 電解回収に限らず，分別処理したスラッジを何らかの形 で再利用，再資源化するにも重要な要因となる。

本報では硫酸銅水溶液に沈殿剂として水酸化ナトリウ ム, 炭酸ナトリウム, 炭酸水素ナトリウムの水溶液を加 え, 生成した沈殿を沪過分離した後の沪液中の残存銅濃 度および生成した沈殿の沪過性, 含水率について検討し た。また固液分離の容易な沈殿から隔膜電解法により銅 を電解回収した結果を報告する。

\section{2. 実験方法}

\section{2-1 汇液中の残存銅濃度}

$0.2 \mathrm{~mol} / 1$ 硫酸銅水溶液 $100 \mathrm{ml}$ に対しビュレットから 沈殿剤水溶液 $(2 \mathrm{~mol} / \mathrm{l}$ 水酸化ナトリウムまたは $2 \mathrm{~mol} / 1$ 炭 酸ナトリウム) を滴下して $\mathrm{pH}$ を $7 ， 8 ， 9 ， 10 ， 11$ に調 整後, 純水を加兄て全量を $200 \mathrm{ml}$ (全銅濃度 $0.1 \mathrm{~mol} / 1$ ) と し, 容器内に密栓状態で所定時間, 一定 温度で熟成し

*甲南大学理学部（干658 神戸市東灘区岡本8-9-1）

Fac. of Sci. Kohnan Univ.,

8-9-1, Okamoto, Higashinada-ku, Kobe 658
た。炭酸水素ナトリウムを沈殿剤とした場 合は，0.2 $\mathrm{mol} / 1$ 硫酸銅水溶液 $1,000 \mathrm{ml}$ に, $1 \mathrm{~mol} / 1$ 炭酸水素ナト リウム水溶液を一定過䅗量加え, 純水で全量を $2,000 \mathrm{ml}$ (全銅濃度 $0.1 \mathrm{~mol} / 1$ ) とし， $80^{\circ} \mathrm{C} て ゙ 10$ 時間熟成を行 なった。所定時間ごとに，スラリー $200 \mathrm{ml}$ を抜さ出し， pHを測定し，沪液中の銅濃度を調べた。沈殿の沪過は， ミリポア沪紙（孔径1. $2 \mu \mathrm{m}$ ) を用いて吸引洰過した。沪 液中の残存銅濃度はキェペラゾン (BCOD) 吸光光度法 および EDTA 滴定法により求めた。

\section{2-2 沪過性と含水率}

2-1 に示した方法で調整したスラリーをトップチャー ジ型リーフテスターを用いて沪過し，沪液量と沪過時間 の関係を調べた。リーフテストの条件は前報2)と同様で

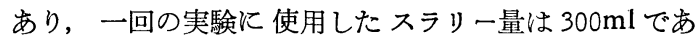
る。

含水率は, リーフテストで得られた湿ケーキを分離し て重量 $\left(W_{1}\right)$ を測定後, $105^{\circ} \mathrm{C}$ の定温乾燥器で恒量にな るまで乾燥し, 乾燥後の重量 $\left(W_{2}\right)$ を測定して次式によ り含水率 $(W)$ を求めた。

$$
W(\%)=-\frac{W_{1}-W_{2}}{W_{1}} \times 100
$$

\section{2-3 隔膜電解法による malachite からの銅の電解回 収}

2-1，2-2の結果より，銅イオンを malachite として沈 殿させることにより，沈殿処理後の沪液の銅濃度は十分 低く, 固液分離が極めて容易で，沈殿の含水率も著しく 低くなることがわかった。スラッジからの銅の電解回収 に際し malachiteは好都合である。 
容積 $1,800 \mathrm{ml}$ 電解槽を $20 \times 10 \times 0.2^{t} \mathrm{~cm}$ のフェルト布で 陽極室と陰極室に区画した。陽極には白金板 $\left(0.5 \mathrm{dm}^{2}\right)$ を，陰極には片面を”絶縁被覆した銅板（有効面積 1.25 $\left.\mathrm{dm}^{2}\right)$ を用いた。電解液には $1 \mathrm{~mol} / 1$ 硫酸銅水溶液を使 用した。陽極室に既知量の銅分を含む malachite を入 れ，電解液を加えて全容を $770 \mathrm{ml}$ とし，同時に陰極室に 電解液1, 020ml を加えて隔膜の両側で液面の高さが等し くなるようにした。な㧤硫酸銅水溶液 $(\mathrm{pH} 3.3)$ を電解 液とした場合，水酸化銅，酸化銅の共析したもろい陰極 析出物が得られたので, 陰極液にあらかじめ $10 \mathrm{~g} / 1$ の硫 酸を添加し，陰極液の $\mathrm{pH}$ を1.5程度とした。陰極室は 空気かくはんを行ない，陽極室も弱い空気かくはんを行 なった。温度 $30^{\circ} \mathrm{C}$, 陰極電流密度 $3 \mathrm{~A} / \mathrm{dm}^{2}$ で電解し, 陽極室に添加した malachiteが完全に溶解すると考兄ら れる理論電気量ごとに所定量の malachiteを陽極室に逐 次添加供給するとともに陰極液, 陽極液の $\mathrm{pH}$ 測定，な らびに陰極液の銅分の分析を行ない，連続して長期間の 電解を行なった。

なお，実際に電気めっき工場において実用規模におけ る硫酸銅系排水からの銅の回収を行ない，必要経費を概 算した。

\section{3. 結果と考察}

\section{3-1＼cjkstart汇液中の残存銅濃度}

水酸化ナトリウムを沈殿剤として加えると青白色コ口 イド状の沈殿を生ずる。沈殿組成は, $\mathrm{pH}$ 滴定の結果よ り, 当量点が $\mathrm{NaOH} / \mathrm{Cu}^{2+}$ モル比1.5にあることから、ほ ぼ $\mathrm{Cu}(\mathrm{OH})_{1.5}\left(\mathrm{SO}_{4}\right)_{0.25}$ と考光られ，硫酸銅初濃度や沈殿 剤の滴下速度によってあまり影響されなかった。熟成に 伴う沪液中の残存銅濃度 (以下 $\mathrm{C}_{\mathrm{R}}$ と呼ぶ), 母液の $\mathrm{pH}$ 変 化を図 1 に示した。熟成に伴い母液の $\mathrm{pH}$ は低下し，同

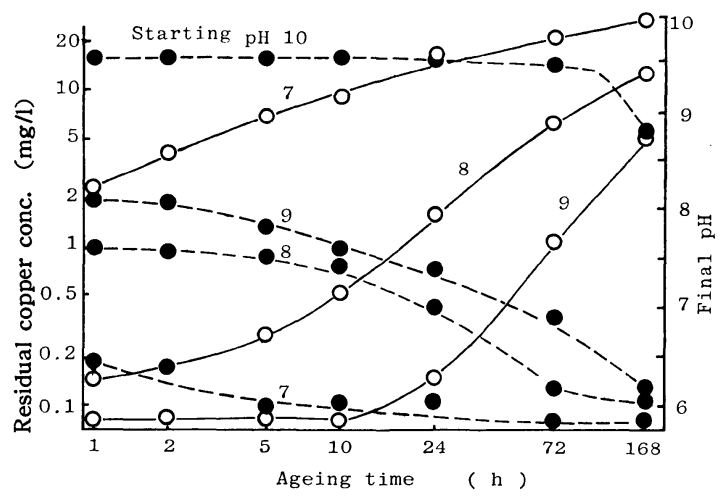

Fig. 1 Variation of residual copper concentration and final $\mathrm{pH}$ with ageing time at $30^{\circ} \mathrm{C}$. Precipitant : $\mathrm{NaOH}$ $\bigcirc$ : Residual copper conc.

: Final pH
時に $\mathrm{C}_{\mathrm{R}}$ は増大した。沈殿生成時の $\mathrm{pH}$ が 10 のさ $30^{\circ} \mathrm{C}$, 1 week 以下の熟成では，いずれの場合も $\mathrm{C}_{\mathrm{R}}<0.05$ $\mathrm{mg} / 1$ であった。熟成に伴う $\mathrm{pH}$ の低下は, $\mathrm{Cu}(\mathrm{OH})_{1.5}$ $\left(\mathrm{SO}_{4}\right)_{0.25}$ が高い $\mathrm{pH}$ 域で母液の $\mathrm{OH}^{-}$と反応して, より安 定な $\mathrm{Cu}(\mathrm{OH})_{2}$ に変化するためと考えられる。図 2 に熟 成後の母液の $\mathrm{pH}$ と $\mathrm{C}_{\mathrm{R}}$ の関係を示した。この結果より, 水酸化ナトリウムを沈殿剤とする場合, $\mathrm{pH} 8$ 付近で沈 殿形成後，直ちに沪別するか，あるいは沪過時の母液の $\mathrm{pH}$ を 7.5 程度として沪別することにより， $\mathrm{C}_{\mathrm{R}}$ は 0.5 $\mathrm{mg} / 1$ 以下となることがわかった。

炭酸ナトリウムを沈殿剤として加えるとき，生成直後 の沈殿は青色コロイド状で沈降体積す大きく比較的沪過 し難いものであるが，長時間室温で熟成するか，または 短時間加温熟成することにより，沈降体積の極めて小さ

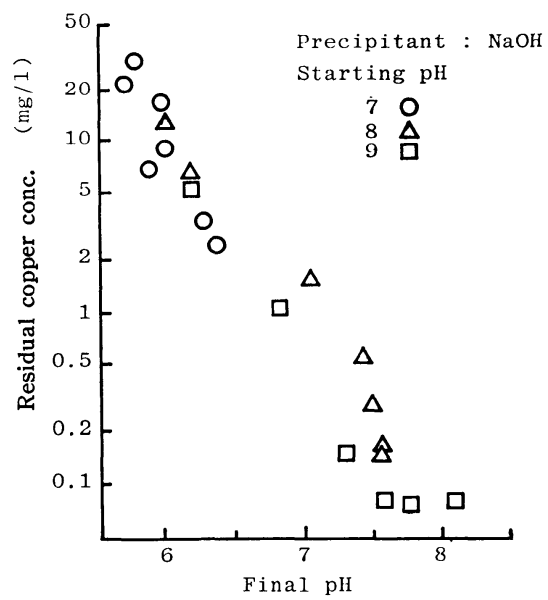

Fig. 2 Relation between residual copper concentration and final $\mathrm{pH}$ in ageing at $30^{\circ} \mathrm{C}$.

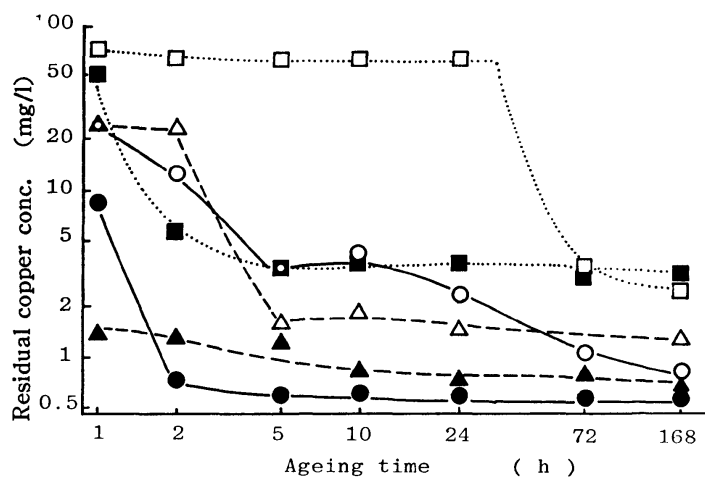

Fig. 3 Variation of residual copper concentration with ageing time in malachite formation. Precipitant : $\mathrm{Na}_{2} \mathrm{CO}_{3} \quad$ Starting $\mathrm{pH}$ Ageing temp. $\quad 7 \quad 8 \quad 9$ $30^{\circ} \mathrm{C}$ $\bigcirc \triangle \square$ $70^{\circ} \mathrm{C}$ 


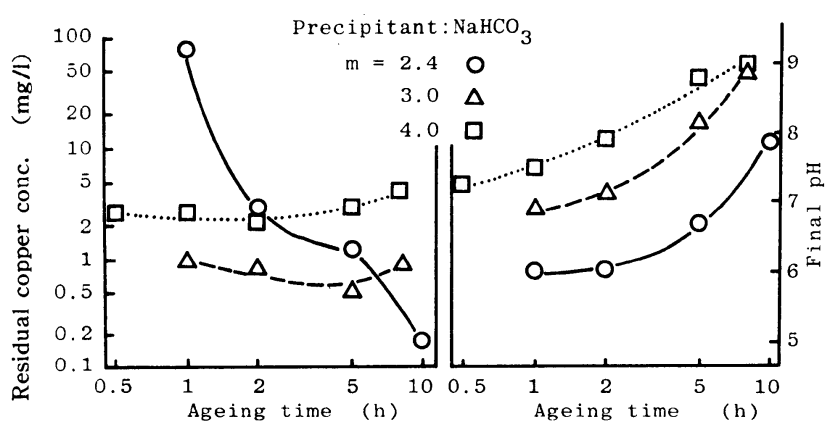

Fig. 4 Variation of residual copper concentration and final $\mathrm{pH}$ with ageing time at $80^{\circ} \mathrm{C}$.

(m ; molar ratio $\mathrm{NaHCO}_{3} / \mathrm{Cu}^{2+}$ )

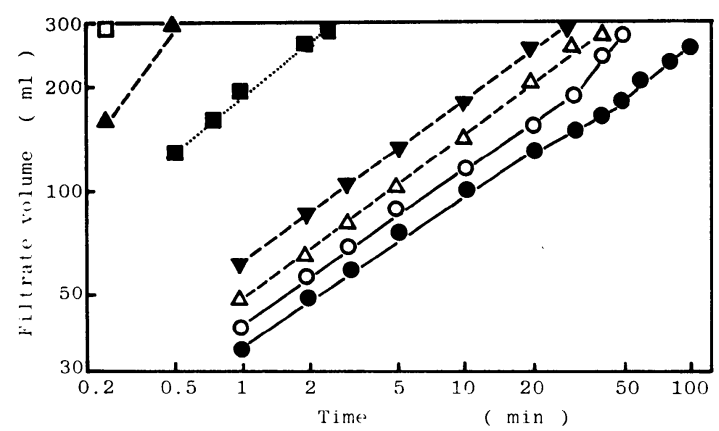

Fig. 5 Fitration characteristic of copper precipitates.

Ageing condition

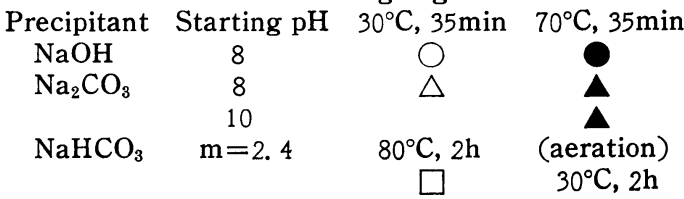

モル比が高いと短時間で malachite 化がお こり, $\mathrm{NaHCO}_{3} / \mathrm{Cu}^{2+}$ モル比が 3 のを $\mathrm{C}_{\mathrm{R}}$ は $1 \mathrm{mg} / 1$ 前後と低い值を示した。

\section{3-2 沪過性と含水來}

リーフテストの結果の一部を図 5 に示し た。水酸化ナトリウムにより生じた沈殿は二 ロイド状で沪過し難く，熟成温度が高いほど 沪過性は悪くなる傾向がみられた。

炭酸ナトリウムを加元て生じる初期の沈殿 の沪過性は，水酸化ナトリウムによる沈殿の それより，やや良好であり，同じ熟成時間で は熟成温度の高いほど沪過速度は大であっ た。 $\mathrm{pH} 8$ ，熟成温度 $70^{\circ} \mathrm{C}$ で35 min 熟成した 沈殿ではすでに malachite化が完了し，この 沪過性は極めて優れていた。 $50^{\circ} \mathrm{C} ， 35 \mathrm{~min} の$ 熟成では $\mathrm{pH} 7 ， 8$ で生成した沈殿が， $70^{\circ} \mathrm{C}$, $35 \mathrm{~min}$ の熟成では $\mathrm{pH} 9$ 以下で生成した沈殿 の malachite 化が起こった。沈殿生成時の pH が低く熟成温度の高いほど malachite 化 した沈殿の沪過速度は大であった。

炭酸水素ナトリウムを加え溶存する二酸化 炭素を除去するため，室温で脱炭酸した空気 を通気した場合，形成された沈殿は malachite 化していないが沪過性は良好であった。 これに比へて $80^{\circ} \mathrm{C}$ で加温熟成し malachite 化した沈殿は，さらに優れた沪過性を示し た。

リーフテスト後の湿ケーキの含水率を測定 した結果を表 1 に示した。水酸化ナトリウム により生じた沈影は $\mathrm{pH}$ が低く熟成温度の高 いほど含水率が低くなる傾向を示したが，いずれの場合 も含水率は高い值を示した。炭酸ナトリウムにより生成 した沈殿でも malachite化していないものの含水率は高 い。炭酸水素ナトリウムを沈殿剤とし常温で脱炭酸した

Table 1 Water content $(\%)$ of copper precipitates.

殿生成時の $\mathrm{pH}$ が $7 \sim 8$ と比較的低く, 熟成温度の高い ときに速やかに起こった。沈殿生成時の $\mathrm{pH}$ が10以上の 場合, malachite 化は起こらず高温で熟成すると水酸化 ナトリウムを沈殿剤として高温で熟成したときと同様に 沈殿は一部黒色の酸化銅に変化した。沈殿生成時 $\mathrm{pH} 8$ とした場合, 沈殿の malachite 化は約 $15 \mathrm{~min}$ で起こっ た。 malachite 化に伴って $\mathrm{C}_{\mathrm{R}}$ は急激に低下したが， malachite 化に伴ら母液の $\mathrm{pH}$ の変化は特にみられなか った。

沈殿剂として炭酸水素ナトリウムを一定過剰量加えて $80^{\circ} \mathrm{C}$ で熟成し， $\mathrm{C}_{\mathrm{R}}$ と $\mathrm{pH}$ の変化を調べた結果を図 4 に示 した。炭酸水素ナトリウムを加えて加温すると二酸化炭 素の発生を伴って次第に $\mathrm{pH}$ が上昇した。 $\mathrm{NaHCO}_{3} / \mathrm{Cu}^{2+}$

\begin{tabular}{|c|c|c|c|c|c|}
\hline \multirow{2}{*}{ Precipitant } & \multirow{2}{*}{ Ageing condition } & \multicolumn{4}{|c|}{ Starting $\mathrm{pH}$} \\
\hline & & 7 & 8 & 9 & 10 \\
\hline \multirow{3}{*}{$\mathrm{NaOH}$} & $30^{\circ} \mathrm{C}, 35 \mathrm{~min}$ & 71.8 & 76.4 & 84.2 & 98.5 \\
\hline & $50^{\circ} \mathrm{C}, 35 \mathrm{~min}$ & 一 & 73.1 & 76.8 & 80.5 \\
\hline & $70^{\circ} \mathrm{C}, 35 \mathrm{~min}$ & - & 69.3 & 75.6 & 81.3 \\
\hline \multirow{3}{*}{$\mathrm{Na}_{2} \mathrm{CO}_{3}$} & $30^{\circ} \mathrm{C}, 35 \mathrm{~min}$ & - & 82.3 & 98.7 & 82.4 \\
\hline & $50^{\circ} \mathrm{C}, 35 \mathrm{~min}$ & 19.7 & 24.4 & 71.4 & 82.2 \\
\hline & $70^{\circ} \mathrm{C}, 35 \mathrm{~min}$ & - & 25.4 & 26.3 & 74.5 \\
\hline \multirow{4}{*}{$\mathrm{NaHCO}_{3}$} & \multirow{3}{*}{$\begin{array}{l}80^{\circ} \mathrm{C}, \quad 2 \mathrm{~h} \\
\text { Aeration } \\
30^{\circ} \mathrm{C}, \quad 2 \mathrm{~h}\end{array}$} & \multicolumn{4}{|c|}{$\mathrm{m}=2.4 \mathrm{~m}=3.0 \mathrm{~m}=4.0$} \\
\hline & & 19.0 & 16.9 & & 7.4 \\
\hline & & 70.4 & 70.9 & & 6.9 \\
\hline & \multicolumn{5}{|c|}{$\left(\mathrm{m} ;\right.$ molar ratio $\mathrm{NaHCO}_{3} / \mathrm{Cu}^{2+}$ ) } \\
\hline
\end{tabular}


空気を通気した場合，図4の結果より沪過速度は比較的 大であるが，含水率はほぼ70\%と高い值を示した。これ は沈殿の結晶化が不完全であるためと思われる。これに 対し malachite化した沈股の含水率は $30 \%$ 以下であり， 十分に malachite化した沈殿は20\%以下の低い值を示し た。

\section{3-3 隔膜電解法による malachite からの銅の電解回} 収

電解に伴う陰極液，陽極液の $\mathrm{pH}$ 変化，陰極液中の銅 イオン量の变化を図 6 に示した。陰極液の $\mathrm{pH}$ は電解を 通してほとんど変化することなく，ほぼ $\mathrm{pH} 1.5$ の值を 保った。陰極液中の銅イオン量も電解初期には若干低下 する傾向がみられたが，電解を通して50～60 gの值を保 った。 malachite は含水率が低いので電解槽への水分の 持込みも少なく，また電解液への分散は良好で溶解性に る優れ理論值とほぼ等しい電気量で完全に溶解した。陰 極電流効率は $100 \%$ で平滑で正常な電着物が得られた。

\section{3-4 電気めっき工場での実施例}

電気めっき工場において実用規模に括ける銅の回収を 行なった。対象とした排液は，硫酸銅めっきの水洗工程 に設置したイオン交換樹脂の再生処理により生じた溶離 液, および銅めっきはく離液（硫酸一過酸化水素系）で ある。これらの溶液に大量に共存する酸を水酸化ナトリ ウムで，ある程度中和したのち炭酸ナトリウムを加光， $\mathrm{pH}$ を 8 と, 蒸気を吹きこんで約 $50^{\circ} \mathrm{C}, 1 \mathrm{~h}$ の加温を行 なっで沪て malachiteを生成させた。これを遠心脱水機 過水洗し供試スラッジとした。これらの操作は730lの処 理槽を用いてバッチで行なった。

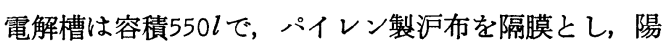

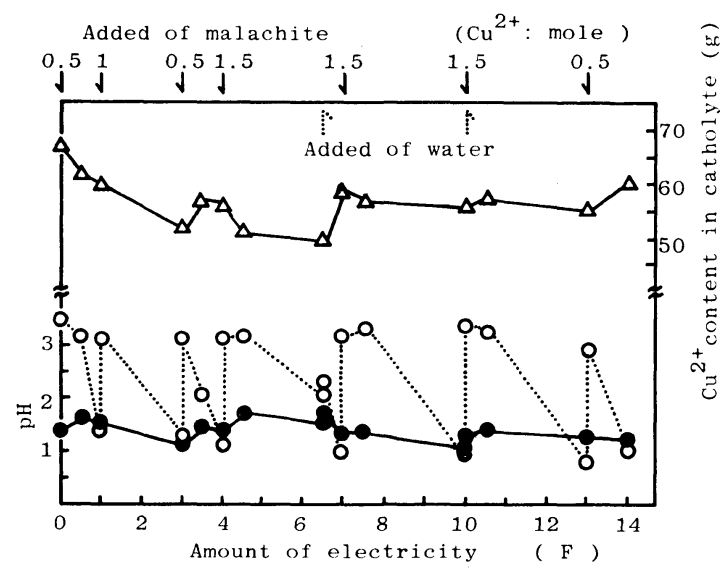

Fig. 6 Electrolytic recovery of copper from malachite. Variation in copper content in catholyte (upper part) and $\mathrm{pH}$ (lower part) during electrolysis.

$\triangle$ : copper content, $\bigcirc$ : anolyte, $\bigcirc$ : catholyte
極室と陰極室に区画した。陽極には鉛板を，陰極には同 じ電解槽中でステンレス鋼板上に $1 \sim 2 \mathrm{~mm}$ の厚さに銅 を電着させ、はがしとったるのを種板として用いた。建 浴時の電解液組成は硫酸銅 $250 \mathrm{~g} / \mathrm{l}$ ，硫酸20g/1であり，陽 極室に逐次 malachiteを供給しながら320～350A（陰極 電流密度 $\left.1.5 \mathrm{~A} / \mathrm{dm}^{2}\right)$ の電流を流し，9.9kg/day の銅を

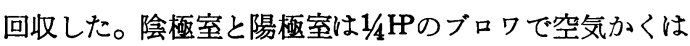
んした。浴温は特に加温を行なわなくても次第に上昇 し，ほぼ $35^{\circ} \mathrm{C}$ に保たれた。電解を通して電解液 (陰極 液）の組成は，ほとんど変化することなく，平滑で正常 な銅が回収された。

回収銅中の不純分を原子吸光法で分析した結果， $\mathrm{Ni}$ $10.6 \mathrm{mg} / \mathrm{kg} ， \mathrm{~Pb} 1.7 \mathrm{mg} / \mathrm{kg}, \quad \mathrm{Fe} 1.3 \mathrm{mg} / \mathrm{kg}$ であり市販 の OFHC 極板泉 より不純物含有量は低い值を示した。 所用電力はブロワの電力費を含め $75 \mathrm{kWh} /$ dayであった。 銅 $10 \mathrm{~kg}$ 当りの処理経費を概算した結果を表 2 亿示した。 水酸化ナトリウムで銅分をスラッジ化し，含水率65\%の スラッジとしてコンクリート固型化（処理費用 34 円 $/ \mathrm{kg}$ ) する場合と比較して，回収金属の価格分だけは有利とな る。この計算には malachite化のための加熱費用, スラ ッジの脱水 (malachite では不要) の費用などを含んで いない。この工場では, このプロセスで現在まで10ケ月 間に合計 $400 \mathrm{~kg}$ の銅を回収し，回収銅はすべてめっき陽 極として自工場内で再利用している。

\section{4. まとめ}

\section{1）銅沈殿の生成条件と諸性質}

水酸化ナトリウムを沈殿剂とした場合, 沈殿生成時 $\mathrm{Cu}(\mathrm{OH})_{1.5}\left(\mathrm{SO}_{4}\right)_{0.25}$ が生成し, 熟成に伴い高い $\mathrm{pH}$ 域に おいて，上り安定な $\mathrm{Cu}(\mathrm{OH})_{2}$ に変化するため，母液の $\mathrm{pH}$ は次第に低下し，これに伴って溶存銅濃度は増大す る。沪液中の残存銅濃度を $0.5 \mathrm{mg} / 1$ 以下とするには, 沈殿生成時 $\mathrm{pH} 8$ 程度とし, 速やかに沪別するか, 沪過 時の母液の $\mathrm{pH} 7.5$ 程度に再調整して沪別する必要があ る。しかし，生成した沈殿は沪過性が悪く含水率も高 い。

Table 2 Estimated operation cost for 10kg copper unit. $\left(\mathrm{Na}_{2} \mathrm{CO}_{3} 75 \mathrm{yen} / \mathrm{kg}, \mathrm{NaOH} 68 \mathrm{yen} / \mathrm{kg}\right.$, Electric power $14 y e n / \mathrm{kWh}$, Official rate for sludge disposal $34 \mathrm{yen} / \mathrm{kg}$ )

\begin{tabular}{lcc}
\hline & with recovery & without recovery \\
Chemicals & $¥ 1,394\left(\mathrm{Na}_{2} \mathrm{CO}_{3}\right)$ & $¥ 954(\mathrm{NaOH})$ \\
Electric power & $¥ 1,050$ (with $\frac{1}{4} \mathrm{IP}$ & - \\
Sludge disposal & \multicolumn{1}{c}{ blower) } \\
Recovered copper & $¥ \triangle 4,500$ & $¥ 1,299$ \\
Total & $¥ \triangle 2,056$ & $¥ 2,253$ \\
\hline \hline
\end{tabular}


炭酸ナトリウムを沈殿剂とした場合， $\mathrm{pH} 7$ ～8 と比 較的低い $\mathrm{pH}$ で沈殿形成後, $50^{\circ} \mathrm{C}, 30 \mathrm{~min}$ 程度加温する ことにより沈殿は緑色結晶性の malachite $\mathrm{Cu}(\mathrm{OH})(\mathrm{CO})$ 0.5 に変化した。 malachite は固液分離が極めて容易で, 沪過操作で含水率20\%程度となる密な沈殿で，しかる沪 液中の残存銅濃度は $0.5 \mathrm{mg} / 1$ 程 度である。 malachite は, めっき工場内での銅の電解回収, 山元還元など, い ずれの形で処分するにしても，他の形のスラッジと比較 して処理が極めて容易である。

2) malachite からの銅の電解回収 malachite は含水率が非常に低く, 電解液への分散 性, 溶解性も良好で電解回収に最適である。実験室での 長期連続電解, ならびに, めっき工場に拈ける実用規模 での電解回収の結果, malachite からの銅の電解回収は 技術的に容易であるだけでなく経済的にも有利であっ た。
終りに本研究に協力して頂いた中島英一郎氏，ならび に工業化実験に協力して頂いた帝国工業秼に厚く感謝す る。な括, 本研究の実施にあたり一部文部省科学研究費 によったことを付記して厚く感謝する。

(昭和52年 5 月, 本協会第55回学術講演大会にて一部 発表)

(1978-2-15受理)

\section{文博}

1）縄舟秀美, 水本省三 川崎元雄；スラッジからの金 属の電解回収, 本誌, 28, 228 (1977)

2）縄舟秀美, 水本省三, 川崎元雄 ; ニッケルスラッシ の生成条件之諸性質, 本誌, 29, 180 (1978)

3) A.K. Graham, H.L. Pinkerton ; Electroplating Engineering Handbook (2nd ed.), p.649 (1962, Reinhold Publishing. Corp.)

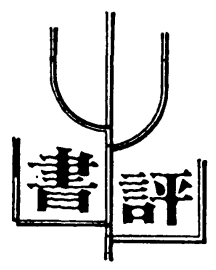

本書は日本プリント回路工業会の環境保全委員会が, 厳しさと複雑さを増した環境保全問題を考えるらえで, 会員の参考にするために編集したものであり，環境保全 関係法律拔粋, 水質污濁防止技術, 測定 - 分析 - 検定方 法, 環境保全関係用語解説, 日本プリント回路工業会関 係規定拉よび付録の各章からなっている。このように幅 広い内容をまとめてあるため, ちょっと知りたい, 調べ たいといらときには，大变便利な本と言えよう。そのう ちで特に第一章の法律抜粋には，法大系の全体の説明に 始玉り, 公害対策基本法, 水質污濁防止法, 下水道法, 毒物及び劇物取締法, 騒音規制法, 廃棄物の処理及び清
掃に関する法律, 労働安全衛生法, 作業環境測定法;，消 防法を中心にこれらの関連施行令, 施行規則, 総理府 令, 基準などが網羅されているので便利であり，本書の 2/3を占めている。

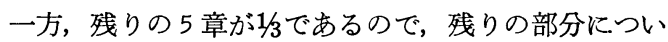
てはややもの足りない感しがしないではない。特に，本 書のタイトルが，環境保全技術入門となっているのであ るから，水質污濁防止技術をはじめとする環境保全技術 の原理や商用例，注意点などについて，もら少し詳しく 書かれていれば一層役立つものになったと惜しまれる。

（横浜国大工 浦野紘平） 